\title{
Dokuma Kumaşlarda İplik Özelliklerinin Giysi Form ve Görünümlerine Etkileri
}

\author{
Neslihan YAŞAR *
}

Özet

Dokuma kumaşları oluşturan en önemli elemanlar iplik ve örgüdür. Bunlarla beraber dokuma kumaşlar, kumaş yapısı, renk, doku, sıklık gibi tasarım elemanlarının bir arada tasarlanması ve dokunmasıyla üretilmektedirler. Bu elemanlar, bilinçli olarak tasarlanıp dokumanın olanakları ile kumaşın farklı özelliklerde üretilmesine olanak sağlarlar. Böylece bazı kumaşlarda renk, doku, örgü, iplik veya bunların birkaçının ön planda olduğu estetik değeri yüksek etkiler oluşur. Günümüzün teknolojik imkanları ve gelişmeleri dokuma kumaşları ileri seviyelere taşımıştır. Bu durum, elyaf ve iplik üretimi teknolojisinin yarattığı iplik çeşitleri, doğal ve yapma lifler ve bunların karışımları ile bağlantılıdır. İplik teknolojisinin yarattığı değişim sağlık, inşaat endüstrisi gibi özel alanların yanında giyim ve ev modasında açıç̧a görülmektedir. Bu makalede, farklı iplik özelliklerini içeren kumaşların dokuma tezgahında arka arkaya dokunarak, giyilebilir bir üründe nasıl kullanılabileceği öneri şeklinde yer almaktadır. Faydalı ve yenilikçi bir yaklaşımla atkı ipliklerinin değişimi sonucu, farklı renklerde, dokularda ve desenlerde dokunan kumaşların kadın giysilerindeki yansımaları incelenmektedir.

Anahtar Sözcükler: Dokuma Tasarımı, Kumaş Modası, Çift Katı Dokuma, Hacimli Kumaş, İplik Özellikleri, İpek, Giysi Formları.

\section{Yarn Features' Effect of the Garment Forms and Aspects to Weaving Fabrics}

\section{Abstract}

The most important components that form woven fabrics are yarn and weave. In addition, woven fabrics are produced by the design and weaving of design components such as fabric structure, colour, fibre and density. These components enable designing deliberately and producing fabric with different features by using the advantages of weaving. Thus, in some fabrics, aesthetically valued effects occur in which colour, fibre, weaving and yarn are at the forefront. Today's technological opportunities and developments carried woven fabrics one step forward. This is related to the yarn types that fibre and yarn technologies produce, natural and artificial fibres and the mixture of these. The change that the yarn technology created can clearly be seen in clothing and home fashions as well as in specific fields like health and construction technologies. In this paper, in which ways the fabrics that include different yarn features could be used on a wearable product by being weaved consecutively on weaving loom is presented with sugguestions. Using fabrics weaved in different colours, texture and pattern by changing the weft yarn in a beneficial and innovative way, seamlessly together on clothes are examined with examples.

Keywords: Weaving Design, Fashion Fabrics, Double Weave, Voluminous Fabrics, Yarn Features, Silk, Cloth Forms. 


\section{Giriş}

Tasarım kavramının varlı̆̆ ve gerekliliği tüm endüstriyel alanlarda olduğu gibi kumaş üretiminde de etkin bir rol oynar. Çünkü tasarım ürünün fayda getireceği alanda sorunları en aza indirmeyi hedeflerken aynı zamanda estetik değerleri içinde barındırmayı esas alır. Kumaşlar da endüstriyel bir ürün olarak insanda beğeni hislerini ortaya çıkaracak derecede dikkatli tasarlanmalıdır. Bu durum kumaşların, tüm dünyayı etkisi altında tutan moda kavra$\mathrm{m}$ ile iç içe olmasıyla da ilgilidir. Kumaş tasarımı ürün ve malzemelerin giderek artan ve aklı zorlayan yanları ile iç mimari ve moda dünyasının ihtiyaçlarına karşılık vermektedir (Gale\&Kaur, 2002: 21).

Günümüzde kumaş modası hem talepleri hem de üretimi arttıran çift taraflı bir sistemdir. Her yıl iki sezon olarak belirlenen giysilik kumaş eğilimleri, tasarımcıları ve üreticileri yeni kumaş görünümlerini araştırmaya ve yaratmaya yöneltmektedir. Moda ve kumaş üretiminde tasarım kavramının önemi, tekstil teknolojisindeki gelişmeleri tetiklemiştir. Malzemedeki gelişmeler kumaşların kullanım alanları arasındaki sınırları kaldırmıştır: spor giyimin günlük dış giyime uzantısı, güvenlikli ve koruyucu kumaşların abiye giysilere olan etkisi buna örnektir. Kendi yollarında ilerleyen bu hareketli üretim alanları artık geleceğin kumaşlarında görülecek olasılıkları ortaya çıkarmıştır (Gale\&Kaur, 2002: 21). Bu yenilikler tasarımcıya giysi ve kumaş modasında daha basit fakat daha iddialı tasarım geliştirme zorunluluğunu getirmiştir. Gelinen son nokta da giysiler, güçlü tasarım alt yapısı ile sanatsal bir ifadeye ya da elektronik veritabanları ile giyilebilir teknolojilere kaymıştır. Yeniçağın giysileri, hem estetik hem de teknolojik açıdan birçok özelliğe sahiptir. Bu çalışmanın konusunu oluşturan dokuma kumaşların özelliği ise hammadde ve iplik türü farklılıklarının giysi formları üzerine etkileri ve giysiler üzerinde yaratacağı görsel ve estetik değerleri ortaya koymaktır.

Çalışmaya konu olan kumaşlar, farklı iplik özelliklerinin tek parça kumaş üzerinde bilinçli bir şekilde birarada kullanılması sonucunda kalıp kullanılmadan basit dikiş yöntemleri ile giysi formuna girecek özellikler taşımaktadırlar. Çalışmanın yönteminde, 'Araştırma Kapsamında Dokunan Kumaşların İncelenmesi ve Giysi Formları Üzerindeki Görsel Etkileri' başlığı altında ayrıntılı olarak incelenen beş farklı özgün giysi örneği, iki aşamalı bir inceleme alanı içermektedir. Dokuma kumaşlarda özgün tasarımlar oluşturarak, görsel ve yapısal farklılıklar elde edilmesinin amaçlanması araştırmanın birinci zeminidir. Önceden tasarlanarak kumaşlarda elde edilen sonuçların kadın giysi formları ve desenleri üzerine etkileri ve yarattıkları görsel sonuçlar ise araştırmanın ikinci zeminidir. Böylece yenilikçi bir bakış açısıyla tasarlanan ve üretilen dokuma kumaşlar giysi formlarının oluşmasına zemin hazırlamışlar ya da farklı birçok doku ve görünümleri bir giysi üzerinde barındırdıkları için fark yaratımışlardır.

\section{Tasarım ve Görsel Etkiler Açısından Dokuma Kumaşlarda Hammadde ve İplik Türlerinin Önemi}

Tasarım alanlarının kendine özgü tasarım elemanları olduğu gibi dokuma kumaşların da tasarım elemanları vardır. Bunlar öncelikle iplik ve örgüdür. Bu iki eleman kumaşın yapı taşlarıdır ki, farklı dokuma teknikleri ile kumaşı oluşturur. Diğer tasarım elemanlarından renk seçimi, desen veya doku, sıklık ve tansiyon farklııkları kumaşın estetik değerlerini oluşturmaktadır.

Hammadde, iplik türleri ve örgünün seçimi kumaşın oluşmasındaki ilk aşamadır. Karmaşık bir düzen gerektiren dokuma eylemi sırasında farklı atkı ipliklerinin kullanılması ile farklı görünümlerde ve dokularda kumaşlar üretmek mümkündür. Bir kumaş, aynı örgü ve kumaş yapısı kullanılarak hammaddeye yani ipliğe bağlı olarak dokulu, pürüzsüz, parlak, mat, şeffaf, kalın, ince, sert, yumuşak olarak dokunabilir.

Hammaddeye bağlı olarak lif ve iplik özellikleri, kumaşın olduğundan daha farklı görsel etkiler kazanmasına sebep olabilir. Resim 1'de görüldüğü gibi özel, gösterişli, lüks görünümlü, parlak, jakarlı kumaşların yanında Resim 2'de ki gibi yeni olmasına rağmen küflenmiş, eskimiş, yırtık pırtık etkiler taşıyan dokuma kumaşlar tasarlamak da mümkündür. 


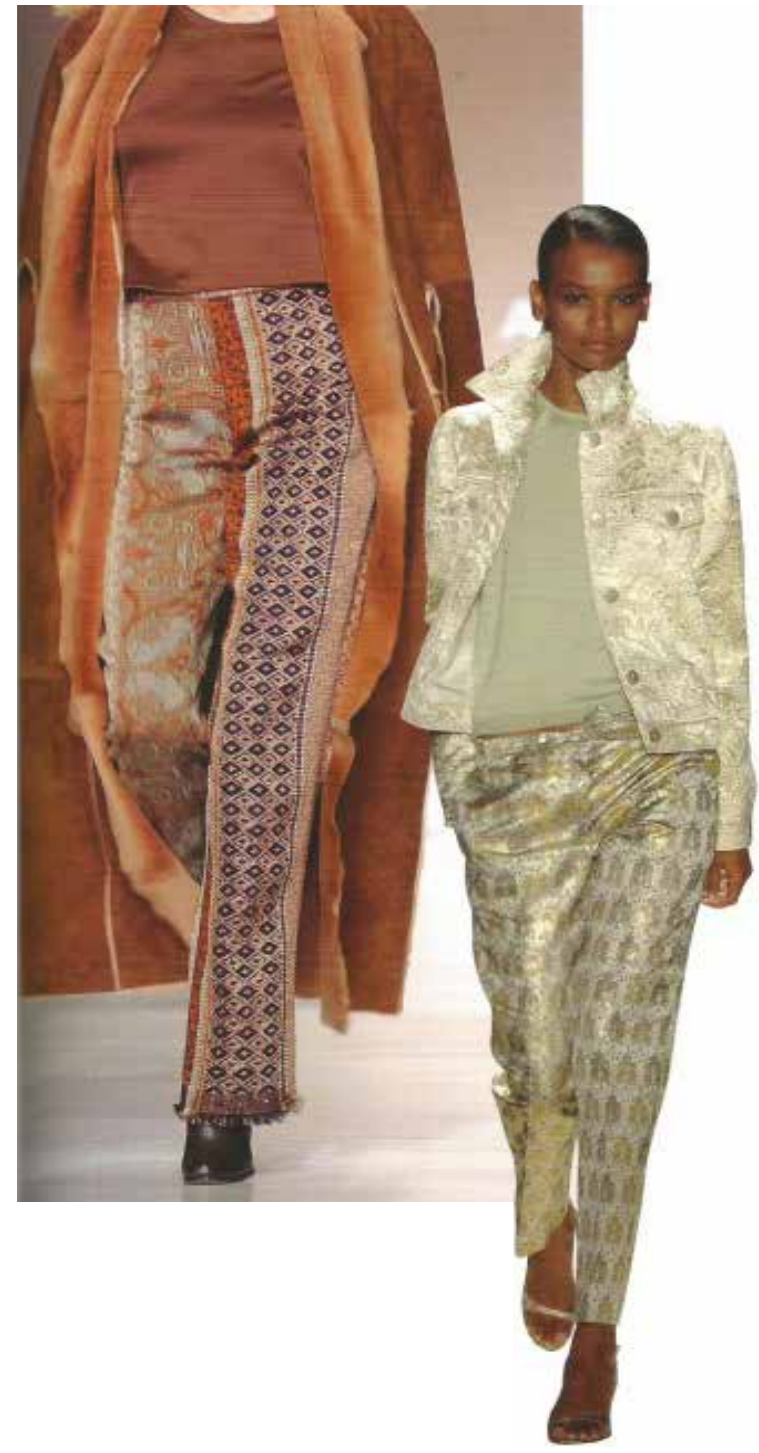

Resim 1. Jakarlı parlak kumaş örneklerinden yapılmış giysi örnekleri

Ne türde olursa olsun kumaşlar, sahip oldukları görünümlerini kazanmaları için iplik özellikleri, örgüleri, kumaş yapıları ve bitim işlemleri ile özel olarak tasarlanmaktadırlar. Amaç ise üretilmemiş olan kumaşı üretmek, farklı, gösterişli yeni görünümler yeni görsel etkiler elde etmektir. Resim 2'de yer alan örnekte eski duvar dokularından yola çıkılarak ipek, pamuk, keten, kağıt ve metalik ipliklerle dokunmuş bir kumaş örneği yer almaktadır. Kumaş özellikle eskimiş bir kumaşın görsel etkilerini taşımaktadır. Bu etkiler farklı fiziksel ve kimyasal özellikler taşıyan iplik türlerinin birlikte kullanımı ve örgü farklılıkları ile elde edilmiştir. Çünkü iplikler türlerine göre farklı parlaklık, doku, ışık etkileşimleri gibi kumaşın görsel etkilerini çeşitlendirebilecek güçlü tasarım öğeleridir.

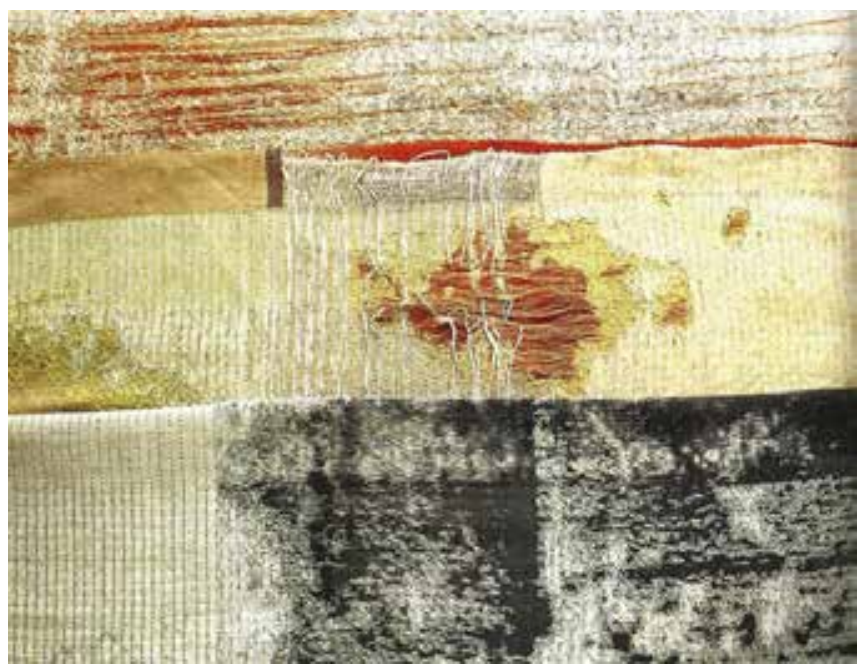

Resim 2. İpek, pamuk, keten, kağıt ve metalik ipliklerle dokunmuş bir kumaş örneği "Indigo Map Stripe" Ismini

Samanidou, $40 \times 175 \mathrm{~cm}$

Resim 3'te, deneysel kumaşların ön plana çıkarıldığı kadın giyimine bir örnek yer almaktadır. Etek kumaşı çift katlı bir kumaştır. İpek ve termoplastik ipliklerle dokunmuş kumaşta iki farklı özellikteki ipliğin birlikte kullanımından doğan doku farkları belli olmaktadır. Termoplastik iplikler ısının etkisiyle çekmiş ve kumaşı büzerek eteğin kumaşının kırışık bir görünüme kavuşmasına sebep olmuştur. İpeğin parlama özelliğinin bu etkileri kuvvetlendirdiği görülmektedir.

Resim 4'te yer alan giysi örneğinde tasarımcı giyen kişinin konforunu düşünürken aynı zamanda giysinin estetik değerlerini de gözetmiştir. Çünkü kumaş vücuttaki nemi doğrudan dışarıya verecek şekilde üretilmiş ipliklerle dokunmuştur.

Giysinin arka yüzü pilili, ön yüzü ise karışık ve dokulu birden fazla iplikle dokunmuş kumaşdan üretilmiştir.

Lif ve iplik özellikleri kumaşın görsel ve kullanım özelliklerini belirleyen en önemli tasarım elemanıdır. Bu özellikler uygun bitim işlemleri ile arttırlıp azaltılabilir. Bir kumaş, ağır gramajlı gibi dururken çok hafif, yumuşak gibi görünürken sert tutumlu olabilir. Dökümlü, akışkan, parlak, mat, şeffaf opak etkiler kumaşların hammadde ve iplik özellikleri ile doğrudan ilişkilidir. 


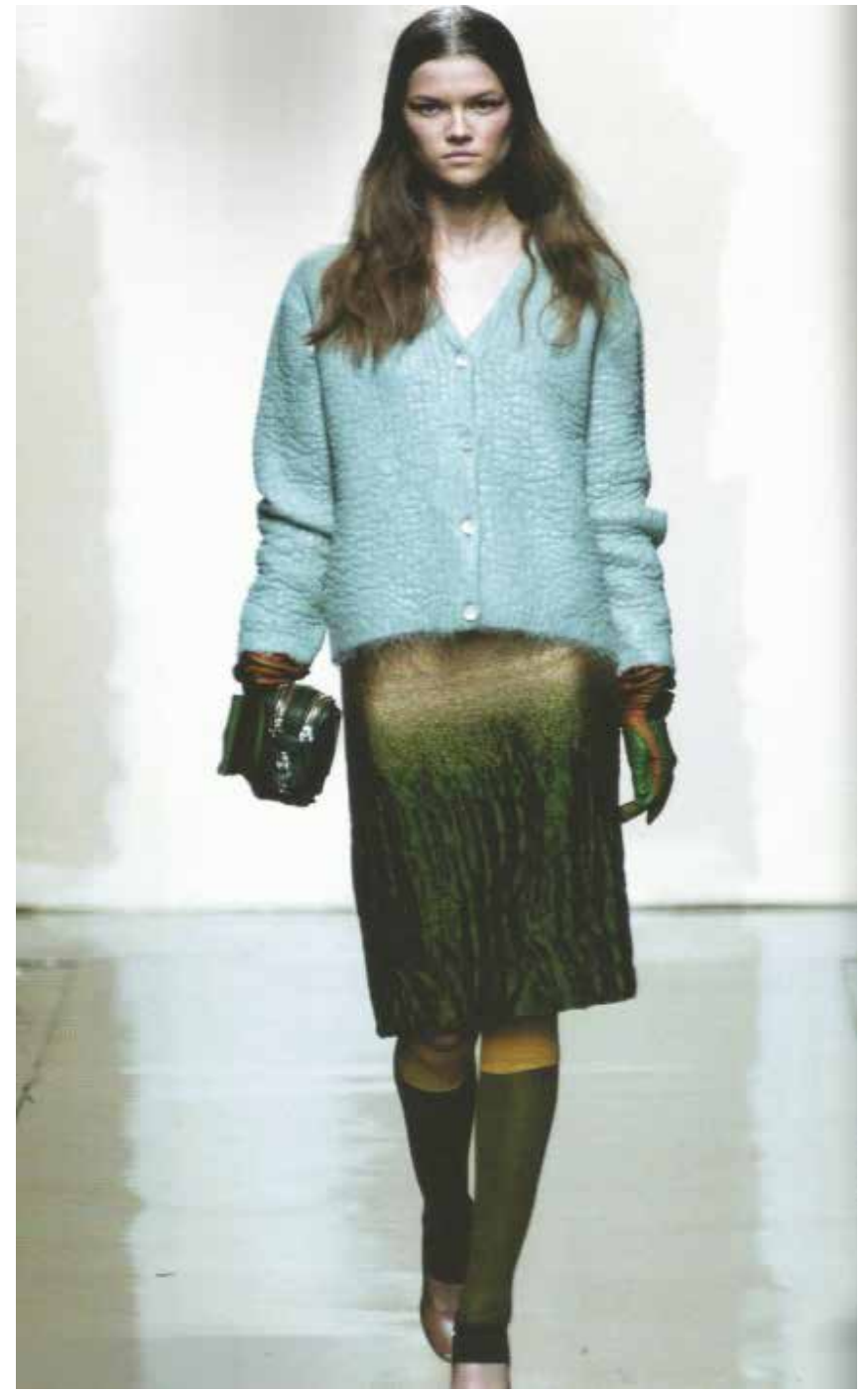

Resim 3. İpek ve termoplastik ipliklerle dokunmuş ve kırışık etkiler taşıyan etek örneği, Prada 2007 Sonbahar-Kış koleksiyonu

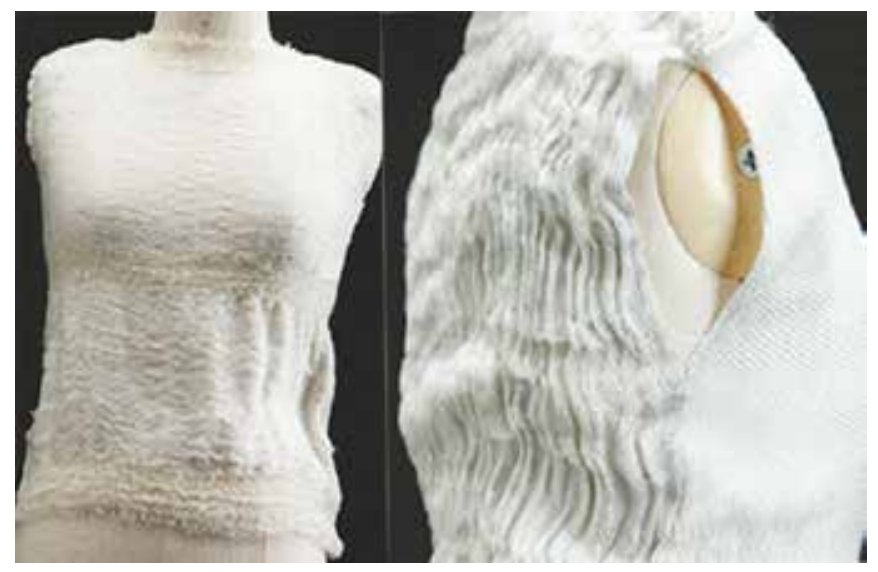

Resim 4. Vücudun nem dengesini sağlayan liflerden üretilmiş giysi

\section{Araştırmanın Esin Kaynakları ve Özellikleri}

Giyim endüstrisinde moda tasarımı ve kadın giyimi üzerine farklı arayışlar, yeni denemeler hep olmuştur. Yeni ve etkileyici giysi üretimi kumaşa da bağlı olarak, sadece giysinin kalıbı ve formunun farklılaştırılıp, geliştirilmesi ile değil, basit giysi modelleri ile birlikte görsel değeri çok yüksek dokulu, hacimli, şeffaf, parlak gösterişli kumaşlarla da verilebilir.

Deneysel kumaş araştırmalarında öncü olan Japon tasarımcıların bu konudaki başarıları, giyim ve kumaş modasını nasıl değiştirdikleri birçok kaynakta yer almaktadır. Bu tasarımcılar doğrudan kumaşlara ya da giysinin kendisine yaptıkları müdahale ile sade fakat gösterişli giysiler tasarlamışlardır. Tasarımcıların koleksiyonlarında yenilikçi fikirler ve güçlü bir araştırma süreci gözlenmektedir. Çalışmaya ilham veren tasarımlarda, giysiler doku, renk ve desen açısından farklılaştırma yoluna gidilmiştir.

Resim 5'te görülen giysi tasarımı tek parça ipek kumaştan üretilmiştir. Kumaş verev kesim yöntemiyle kimono benzeri, bol, düz hatları olan bir elbiseye dönüşmüştür. Tek parça kumaştan tasarlanan yeşil elbiseyi farklılaştıran özellik, bölgesel olarak uygulanan shibori-bağlama-boyama tekniğidir. Shibori tekniği elbisenin düz kumaşına hacim, renk ve doku kazandırmış tasarımın görsel etkilerini güçlendirmiştir. Düz ve pürüzsüz ipek kumaşın belli kısımlarında tam tersi dokulu bir yüzey yaratmıştır.

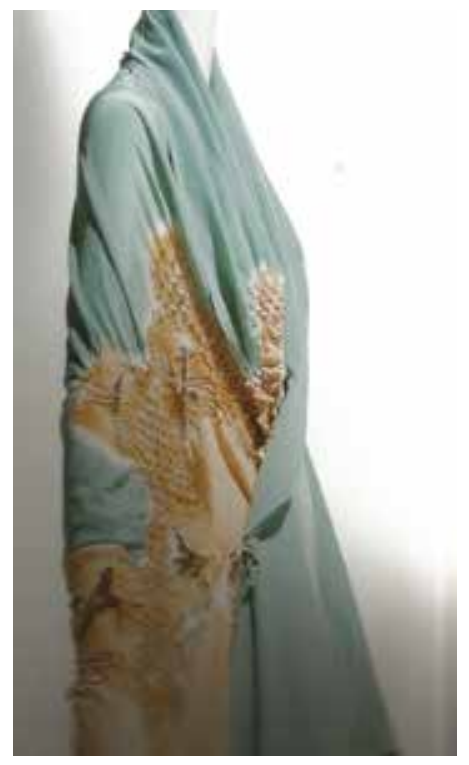

Resim 5. Bir bölümüne shibori uygulanmış tek parça kumaştan tasarlanmış elbise örneği.“Coat Dress”, Yohji Yamamato, İlkbahar-Yaz Koleksiyonu, 1995 
Resim 6'da görülen uzun ceket formundaki keten ve rafyadan üretilmiş kumaş, şaman ritüellerden esinlenilerek tasarlanmıştır. Giysinin kolları, yakası ve üst bedenindeki kırışıklıklar ve büzgülü doku, Resim 7'daki kırmız elbisede görülen bağlama yöntemindeki gibi sonradan yapılan müdahale sonucu elde edilmiştir. Keten ve rafya ile dokunmuş kumaştan üretilen giysiye bölgesel müdahale ile farklı dokular kazandırılmış ve görünümü değiştirilmiştir.

Resim 7'de görülen basit formdaki elbise düz tafta bir kumaştan üretilmiştir. Aynı resmin solunda uygulanmış bölgesel bağlama yöntemiyle elbisenin üst bedeni, uzun kolları ve yakası, abartılı kırışık ve buruşuk bir dokuya sahip olmuştur. Böyle bir yöntem kullanarak Miyake tasarımını düz ve minimal etkiden çıkarıp dikkat çekici, sıra dışı bir görünüme kavuşturmuştur.

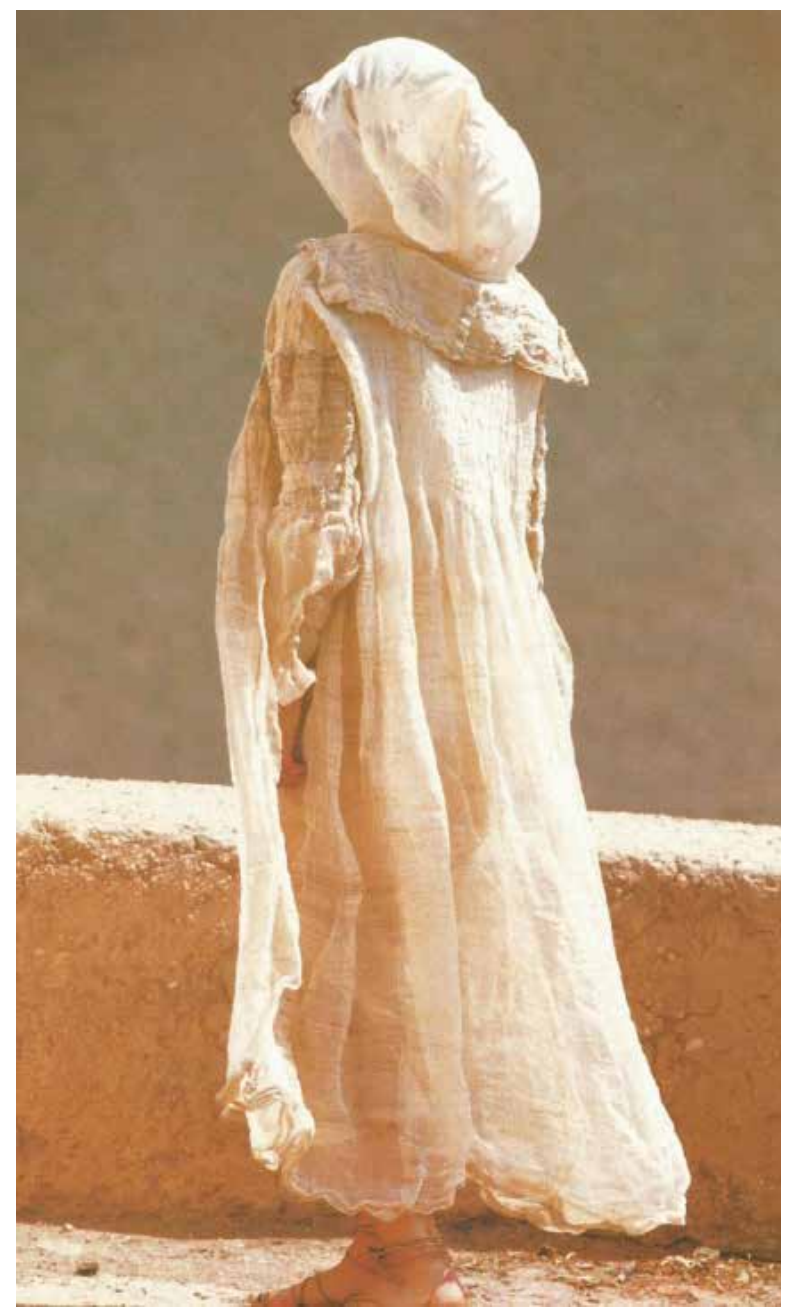

Resim 6. "Shrunk Kibira”, Keten ve rafya ipliklerle dokunmuş kumaştanüretilmiş ceket. Issey Miyake 1993 İlkbahar-Yaz koleksiyonu
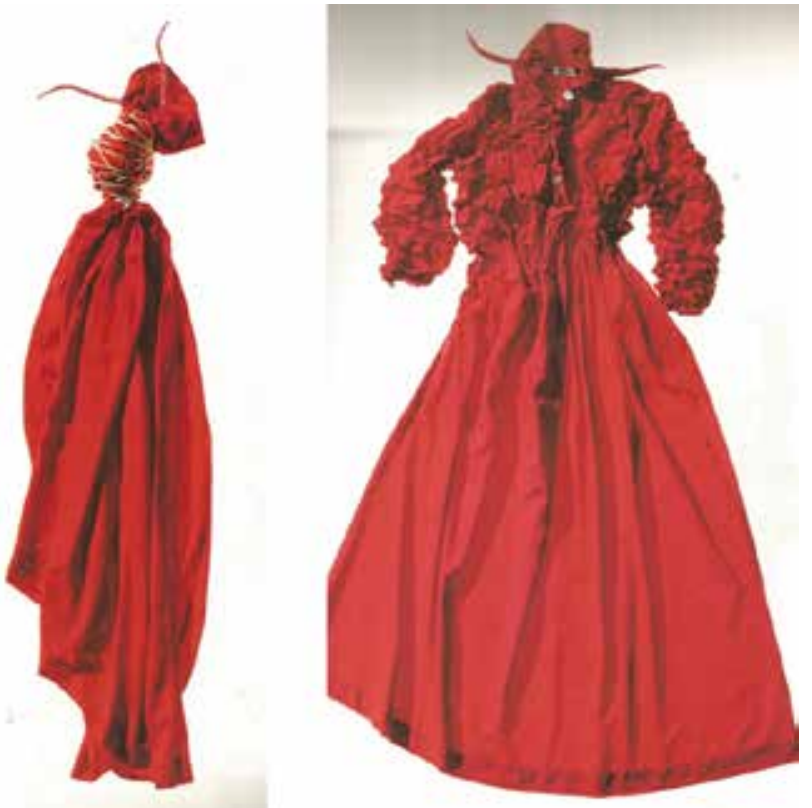

Resim 7. "Partially Crushed \& Tied”, Bağlama yöntemiyle kırıştırılmış ve bölgesel müdahale ile değiştirilmiş giysi örneği. Issey Miyake 1993/94 Sonbahar-Kış koleksiyonu

Miyake'nin tasarımlarının başlangıç noktası çok basit bir ifadeyle 'bir parça kumaş'tan (a peace of cloth- A-POC) gelmektedir. Baş harflerinden oluşan A-POC koleksiyonlarının özü gerçekten de 'bir parça kumaştan giyinmek' fikriyle ortaya çıkmıştır. Bu koleksiyonlar, tüp şeklinde üretilen jakarlı örme kumaş toplarından, bir bilgisayar programı kullanılarak yenilikçi bir yaklaşımla elbise, tişört, etek gibi giysilerin hazır olarak elde edilmesi ve dikiş kısımlarından kesilmesi ile üretilmektedir (Fukai, 2006: 698) (Resim 8).

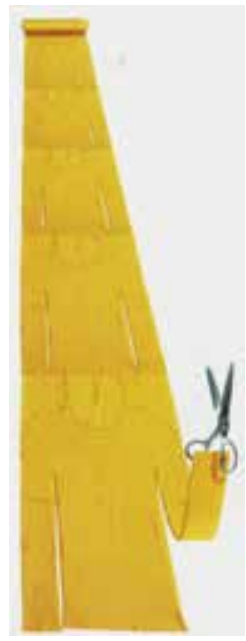

Resim 8. A-POC koleksiyonundan bir parça. Uzun veya kısa kollu olarak giyilecek tişört rulosu. "Yellow Baguette Roll”, Issey Miyake 
Bu araştırma böyle bir düşünce yapısıyla, dokumanın olanakları kullanılarak, tek bir parça kumaş üzerinde farklı doku ve desenler oluşturacak şekilde tasarım yapılabileceği fikri ile gerçekleştirilmiştir. Araştırma kapsamında Japon Tasarımcıların giysileri farklılaştırmak için uyguladıkları yöntemler yerine dokumanın olanaklarından yararlanılarak kumaşlar üzerinde farklı görsel etkiler elde edilmeye çalışılmıştır. Dokuma tekniği, iplik türü, örgü, kumaş yapısı, kumaş sıklığı gibi dokuma tasarım öğelerinin yardımıyla aynı kumaş üzerinde birbirinden farklı dokulara ve görsel etkilere sahip kumaşlar üretilmiştir. Bu araştırmada hammadde ve iplik türü farklılıklarının dokuma kumaş tasarımındaki önemi araştırılmış ve kumaşlar üzerinde elde edilen farklı doku ve desenler giysileri farklılaştırmak için kullanılmıştır.

\section{Malzeme ve Yöntem}

Kumaşların üretiminde hammaddesi doğal malzeme olan ipek, keten, pamuk ipliklerle birlikte yapay ipliklerden elastan içeren polyester iplik, yüksek teknoloji ürünü reflektif iplik kullanılmıştır. Kumaşlar üzerinde parlak-mat, dokuludokusuz, hacimli-düz, şeffaf-opak, açık-koyu renk gibi birbirine zıt kumaş görünümleri elde edilmiş ve bu görünümler giysilerde kullanılmıştır.

Kumaşlar 8 çerçeveli, armürlü, motorlu dokuma tezgahında, tek katlı, değişen yüzlü, çift katlı dokuma yapısı oluşturulacak şekilde tasarlanmıştır. Bu amaçla grup tahar yapılarak hazırlanan çözgü üzerinde kumaşlar arka arkaya dokunmuştur. Çözgüler belli bir düzende 1-2-3-4 ve 5-6-78 numaralı çerçevelere grup olarak sıra tahar yapılmıştır. Çözgü sıklığı 36 tel/cm olarak bütün kumaşlarda aynıdır. Ancak çift katlı dokuma yapısına sahip olan tasarımlarda tek kat için sıklık 18 tel/cm dir. Kumaş sıklık değerleri Tablo 1 de yer almaktadır.

\begin{tabular}{|c|c|c|}
\hline Kumaş & Atkı Sıkhığı & Çözgü Sıklığı \\
\hline 1 "Hayalperest" & $\begin{array}{l}24 \mathrm{tel} / \mathrm{cm} \\
\text { (tek kat için } 12 / \mathrm{cm})\end{array}$ & $\begin{array}{l}36 \mathrm{tel} / \mathrm{cm} \\
\text { (tek kat için 18/cm) }\end{array}$ \\
\hline 2 'Antik' & $\begin{array}{l}24 \mathrm{tel} / \mathrm{cm} \\
\text { (tek kat için } 12 / \mathrm{cm})\end{array}$ & $\begin{array}{l}36 \mathrm{tel} / \mathrm{cm} \\
\text { (tek kat için 18/cm) }\end{array}$ \\
\hline 3 'Kırmızı Güç' & $\begin{array}{l}24 \mathrm{tel} / \mathrm{cm} \\
(\text { tek kat için } 12 / \mathrm{cm})\end{array}$ & $\begin{array}{l}36 \mathrm{tel} / \mathrm{cm} \\
(\text { tek kat için } 18 / \mathrm{cm})\end{array}$ \\
\hline 4 'Şımarık' & $\begin{array}{l}20 \mathrm{tel} / \mathrm{cm} \\
(\text { tek kat için } 10 / \mathrm{cm})\end{array}$ & $\begin{array}{l}36 \mathrm{tel} / \mathrm{cm} \\
(\text { tek kat için } 18 / \mathrm{cm})\end{array}$ \\
\hline 5 'Marjinal' & $24 \mathrm{tel} / \mathrm{cm}$ & $36 \mathrm{tel} / \mathrm{cm}$ \\
\hline
\end{tabular}

Tablo 1: Kumaşların çözgü ve atkı sıklık değerleri

\section{Araştırma Kapsamında Dokunan Kumaşlarda Kullanılan İplikler ve Özellikleri}

Kumaşların üretilmesinde çözgüde 120/2 denye ipek iplik, atkıda 60/2 denye ipek iplik , 60/2 denye-150 tur krep ipek iplik, 20/1 Ne keten iplik, 30/1 Ne pamuk iplik, elastan içeren 28/1 Nm PES (\%60), 78dtex PES(\%40) iplik, 17/1 Nm reflektif iplik kullanılmıştır. Çözgü ve atkı iplikleri olarak kullanılan ipek ipliklerde serisin maddesi vardır ve sert bir yapıdadırlar.

Reflektif iplikler, içine çok küçük cam boncukların yerleştirildiği ipliklerdir. Düz bir polyester filminin üzerine reflektif filmin kaplanması yöntemiyle elde edilir. (1 inch ${ }^{2}$ lik reflektif filmde 50000 adet çok küçük cam boncuk bulunur). İpliğin üzeri, ışığı kaynağına geri yansıtan cam boncukların yer aldığı bir maddeyle kaplanmıştır. Polyester film rulo biçiminde üretilir ve istenen genişliklerde inceltilir (Cohen ve Johnson, 2012: 261).

Elastan iplikler hammaddesi kauçuk olan , \%100 esneme ve eski haline dönme özelikleri olan yapma bir ipliktir (Cohen ve Johnson, 2012: 50). Filament halindeki ipliklerle birlikte kullanılmaya uygundur.

\begin{tabular}{|c|c|c|c|}
\hline \multirow{2}{*}{ Kumas } & \multicolumn{2}{|c|}{ Atki Ipltsi } & \multirow{2}{*}{ Cörzgü Iplitý } \\
\hline & Ön yüz & Arka yüz & \\
\hline \multirow[t]{2}{*}{1 "Hayalperest" } & 60/2 Denye ipek & 60/2 Denye ipek & \multirow[t]{2}{*}{ 120/2 Denye ipek } \\
\hline & 60/2 Denye ipek & $\begin{array}{l}28 / 1 \mathrm{Nm} \text { Pes } \\
\text { 78dtex lyera }\end{array}$ & \\
\hline \multirow{2}{*}{2 'Antik' } & 60/2 Denye ipek & $20 / 1$ Ne keten & \multirow{2}{*}{$120 / 2$ Denye ipek } \\
\hline & $\begin{array}{l}60 / 2 \text { Denye krep } \\
\text { ipek }\end{array}$ & $20 / 1$ Ne keten & \\
\hline \multirow{2}{*}{3 'Kırmiza Gû' } & $60 / 2$ Denye ipek & $20 / 1$ Ne keten & \multirow[t]{2}{*}{ 120/2 Denye ipek } \\
\hline & $\begin{array}{l}60 / 2 \text { Denye krep } \\
\text { ipek }\end{array}$ & $20 / 1$ Ne keten & \\
\hline \multirow[t]{2}{*}{4 'Șımarık' } & $\begin{array}{l}17 / 1 \mathrm{Nm} \text { reflektif } \\
\text { iplik }\end{array}$ & $30 / 1 \mathrm{Ne}$ pamuk & \multirow[t]{2}{*}{ 120/2 Denye ipek } \\
\hline & $\begin{array}{l}17 / 1 \mathrm{Nm} \text { reflektif } \\
\text { iplik }\end{array}$ & $60 / 2$ Denye ipek & \\
\hline \multirow{2}{*}{5 'Marjinal' } & \multicolumn{2}{|c|}{ 60/2 Denye ipek } & \multirow{2}{*}{$120 / 2$ Denye ipek } \\
\hline & \multicolumn{2}{|c|}{ 30/1 Ne pamak } & \\
\hline
\end{tabular}

Tablo 2: Kumaşlarda kullanılan iplikler ve numaraları

\section{Araştırma Kapsamında Dokunan Kumaşların İncelenmesi ve Giysi Formları üzerindeki Görsel Etkileri}

Araştırma kapsamında 5 farklı dokuma kumaş tasarımı ve üretimi yapılmıştır. Aynı tahar ve çözgüyle, çözgü değiştirmeksizin atkı ipliği farklılıkları ile doku, yapı, tutum ve desen farklılıkları elde edilerek giysi formları üzerindeki 
kullanım şekilleri ve oluşturduğu görsel etkiler değerlendirilmiştir. Kumaşlarda tasarlanan hacimli-düz, dökümlü-hafif, yumuşak-sert, opak-şeffaf gibi doku özelliklerinin giysi formları üzerinde çeşitlilik yaratması amaçlanmıştır.

Resim 9 ve 10'da yer alan kumaşlar aynı dokuma tezgahında, aynı çözgüde, farklı iplik türleri ile arka arkaya üretilmiş, tek-çift katlı dokuma yapısına sahiptirler. Örgü, kumaş yapısı, sıklık gibi dokumayı oluşturan tüm özellikleri aynıdır. Kumaş rips ve bezayağı örgülerinden oluşmaktadır. Kumaşın üzerinde elde edilen doku, tutum ve görsel etkilerdeki farklııklar sadece iplik türüne yani atkı ipliği değişimi sonucudur. Resim 9 da görülen kumaş dokusu ham ipek iplikleriyle üretilmiş olduğundan görsel olarak yarı-şeffaf, hafif ve sert özellikler taşırken Resim 10'da görülen kumaş dokusu elastan içeren atkı ipliğine bağlı olarak opak, hacimli, renk değişiminden dolayı dokusunu ön plana çıkaran gösterişli bir yapıdadır.

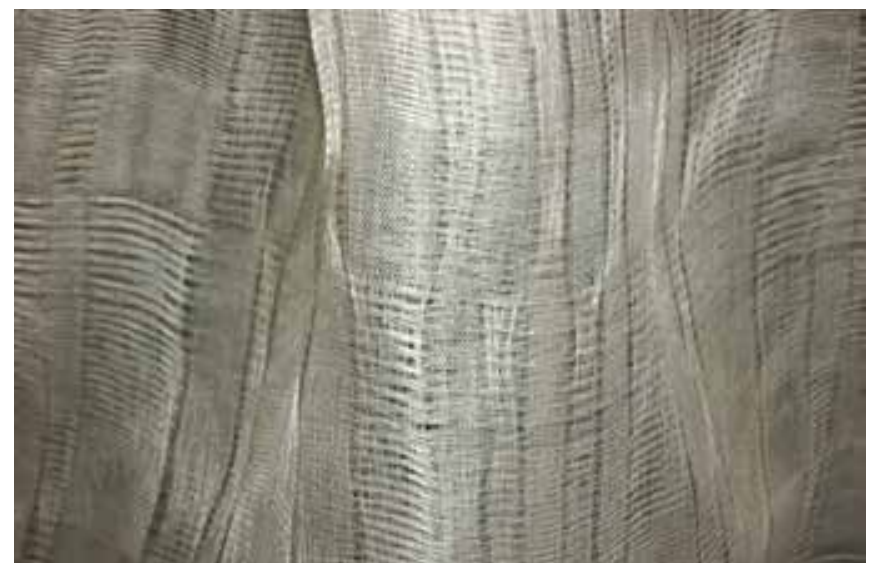

Resim 9. Kumaşın ipek atkı ipliği ile dokunan bölümü, detay, Neslihan Yaşar

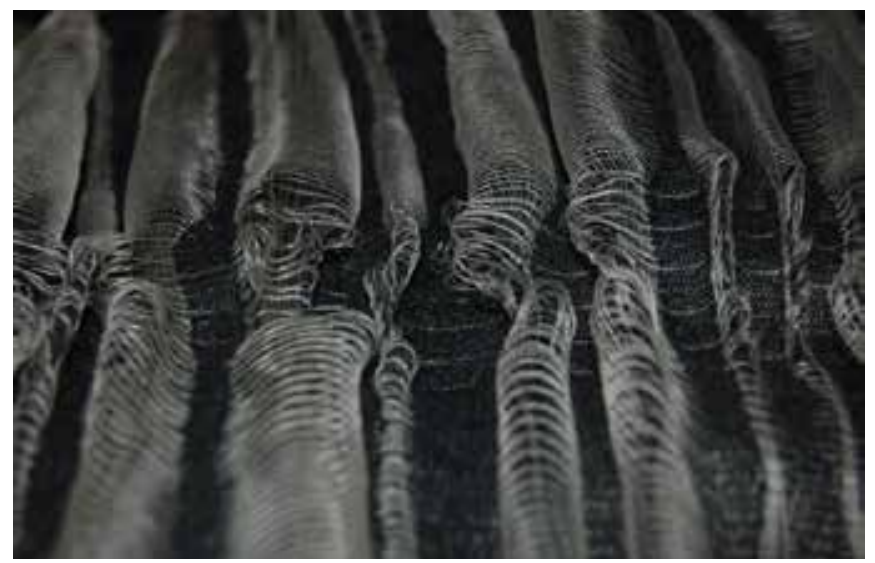

Resim 10. Kumaşın elastan atkı ipliği ile dokunan bölümü, detay, Neslihan Yaşar
Kumaşın bütününde birinci katında gerçekleştirilen atkı ipliği değişimi ile her iki kumaş dokusu bambaşka görsel etkilere sahip olmuştur. Resim 12'de ipek ve elastan içeren atkı ipliklerinin değişimi sonucu iki farklı kumaş dokusu birlikte görülmektedir. Elbisenin bu bölümünde kumaşlar dikişle birleştirilmeden tamamen atkı ipliklerinin yarattığı bir değişimle giysiye bel formunu kazandırmıştır. Elastan ipliğin özelliğinden dolayı kumaş eni daralmış ve bir giysi kalıbından faydalanılmış gibi, Resim 11 'deki giysinin üst bedene tam olarak oturmasına yardımcı olmuştur. Kumaş bedenin sağ ve sol ortasına denk gelen yerlerden dikilerek birleştirilmiştir. Çözgü ve atkıda kullanılan ipek iplikler serisin maddesi ile kaplı olduğu için sert, yarı şeffaf yağı ıağıt hissini yaratan bir tutumdadır.

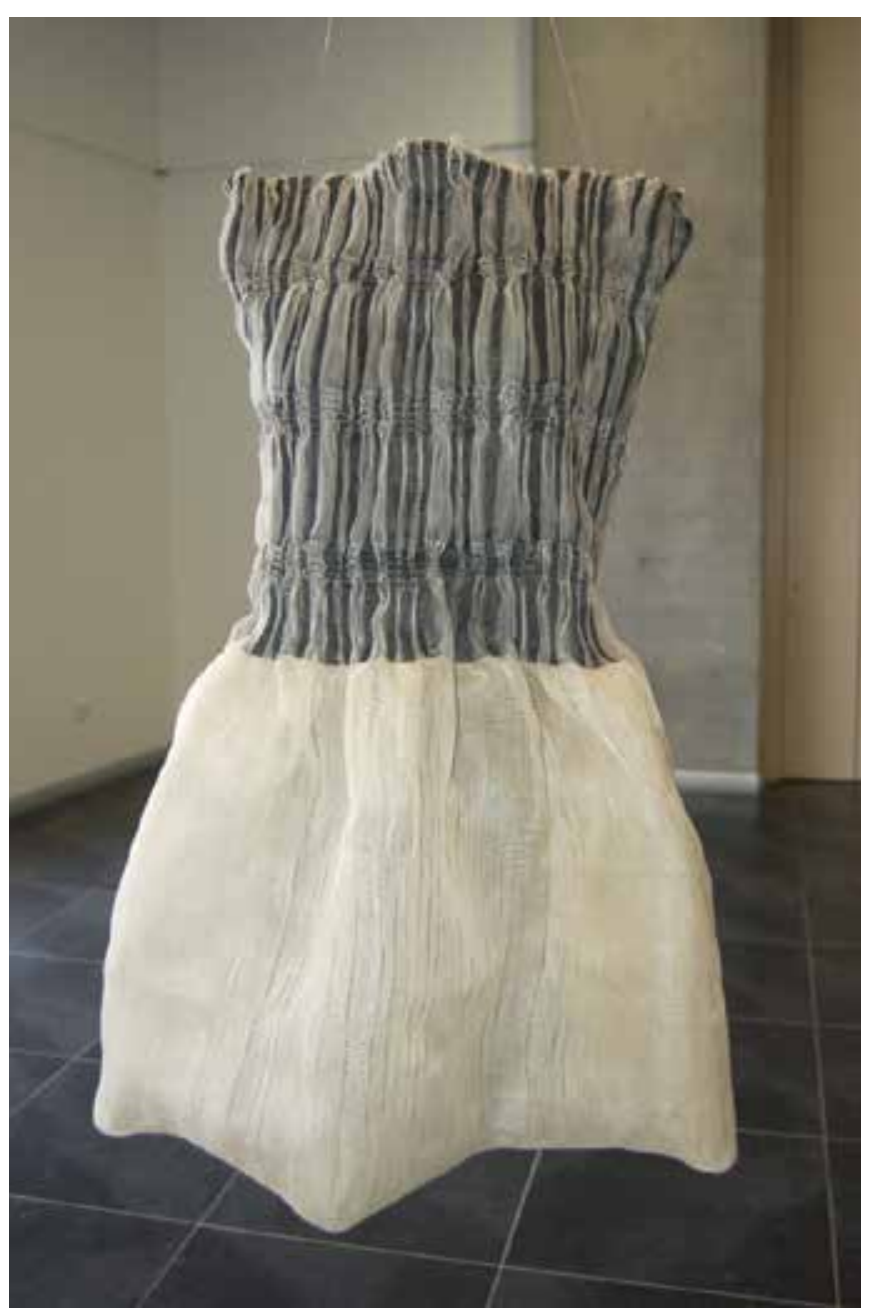

Resim 11. “Hayalperest”, Neslihan Yaşar, 2015

Resim 13'te yer alan 'Antik' adlı çalışma, ön eteği uzun arkası kısa olan bluz tek parça kumaştan oluşmakta- 


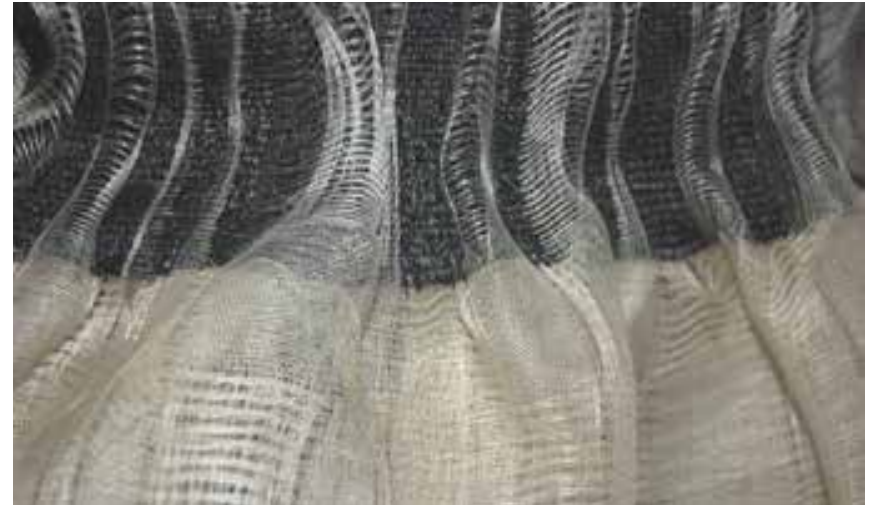

Resim 12. “Hayalperest”adlı çalışmanın detayı

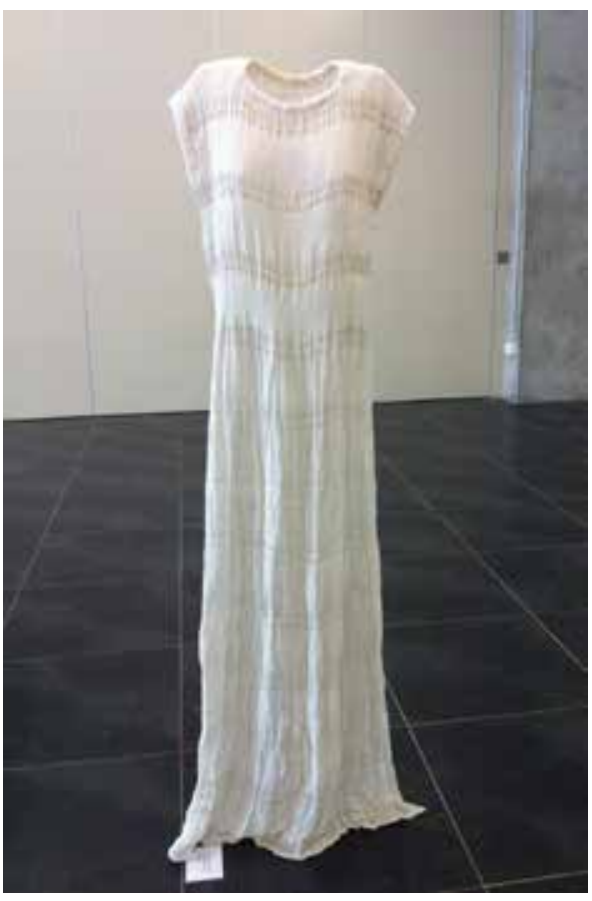

Resim 13. 'Antik' , Neslihan Yaşar, 2015

dır. Kumaş değişen yüzlü çift katlı enine çizgili desenlidir. Kumaşta sadece bezayağı örgüsü kullanılmıştır. Kumaşın birinci katında keten atkı ipliği ve ikinci katında ipek ve krep ipek ipliği kullanılmıştır. Resim 11'deki elbiseye yapısal olarak benzemektedir. Kumaşın üst bedene denk gelen bölümünde kumaşın ikinci katında krep ipek ipliği kullanılmıştır. Alt bedene denk gelen bölümünde ise kumaşın ikinci katında bükümü normal olan ipek ipliği yer almaktadır. Resim 14'de ipek ve krep ipek atkı ipliklerinin yer değiştirdiği bel bölgesi görülmektedir. Kumaşın ön yüzüne çıkan keten atkı ipliklerinin üst tarafında, krep ipek ipliğinin dokusu ve kumaşta yarattığı sıkıştırma, alt tarafında ise normal büküm ipek ipliğinin kumaşta yarattığı parlak, yarı-şeffaf ve büzgülü doku yer almaktadır.

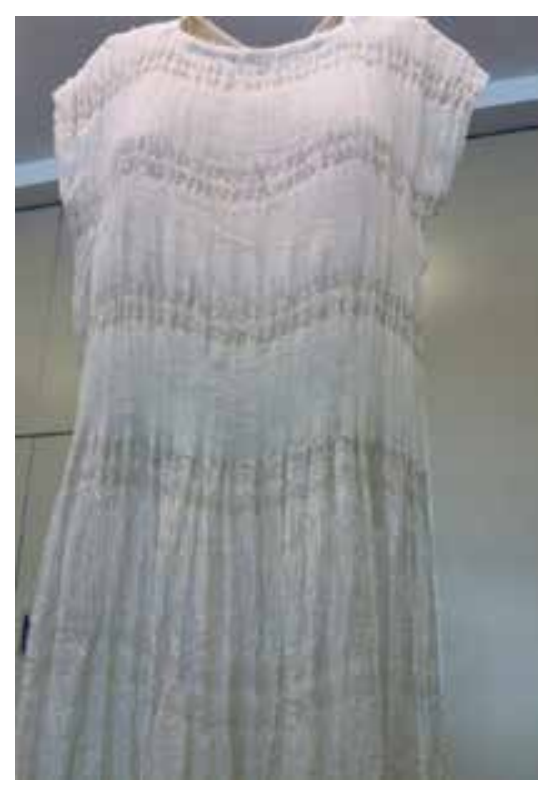

Resim 14. 'Antik' adlı çalışmanın detayı

Ancak bu giysi örneğinde krep ipek ipliğinin yoğun bükümünün ortaya çıkarılması için bitim işlemi uygulanması gerekmiştir. Bitim işleminden sonra krep ipek atkı iplikleri çekerek kumaş enini daraltmış kumaşın yüzeyinde enine çizgili, desenle bağlantılı olarak 'Hayalperest' adlı çalışmaya göre daha az kabarık bir kumaş yüzeyi oluşturmuştur. Bitim işlemi aynı zamanda ipeğin yumuşamasını, parlamasını ve dökümlü bir tutum sergilemesini sağlamıştır. Bluzun etek bölümünde ipek atkı iplikleri nedeniyle kumaşın ön yüzeyi parlak, ışıltılı ve pürüzsüzken atkı ipliğinin değiştiği üst bedende mat ve pürüzlü, pütürlü bir doku oluşmuştur. Bunun sebebi yoğun büküm verilerek oluşturulan krep ipek atkı ipliklerin düzgün yapılarının ve parlama özelliğinin oldukça azalmasıdır. Kumaş çift katlı olarak üretilmesine rağmen oldukça hafif ve yumuşak tutumludur. Etek bölümünde görülen kumaş dokusu yarı-şeffaf etkiler taşımaktadır. Bunun sebebi özellikle seçilen iplik numaraları ve atkı çözgü sıklı̆ı̆ değerleridir

Resim 15'te görülen 'Kırmızı Güç' adlı çalışma, değişen yüzlü tek-çift katlı enine kalın çizgili tek parça kumaştan üretilmiştir. Kumaşta kullanılan örgü bezayağıdır. Elbisenin kumaşı iki farklı atkı ipliği kombinasyonu (ipekketen ve ipek-krep ipek) ile dokunmuş ve elde boyama yapılarak renklendirilmiştir. Elbisenin üst beden bölümüne 


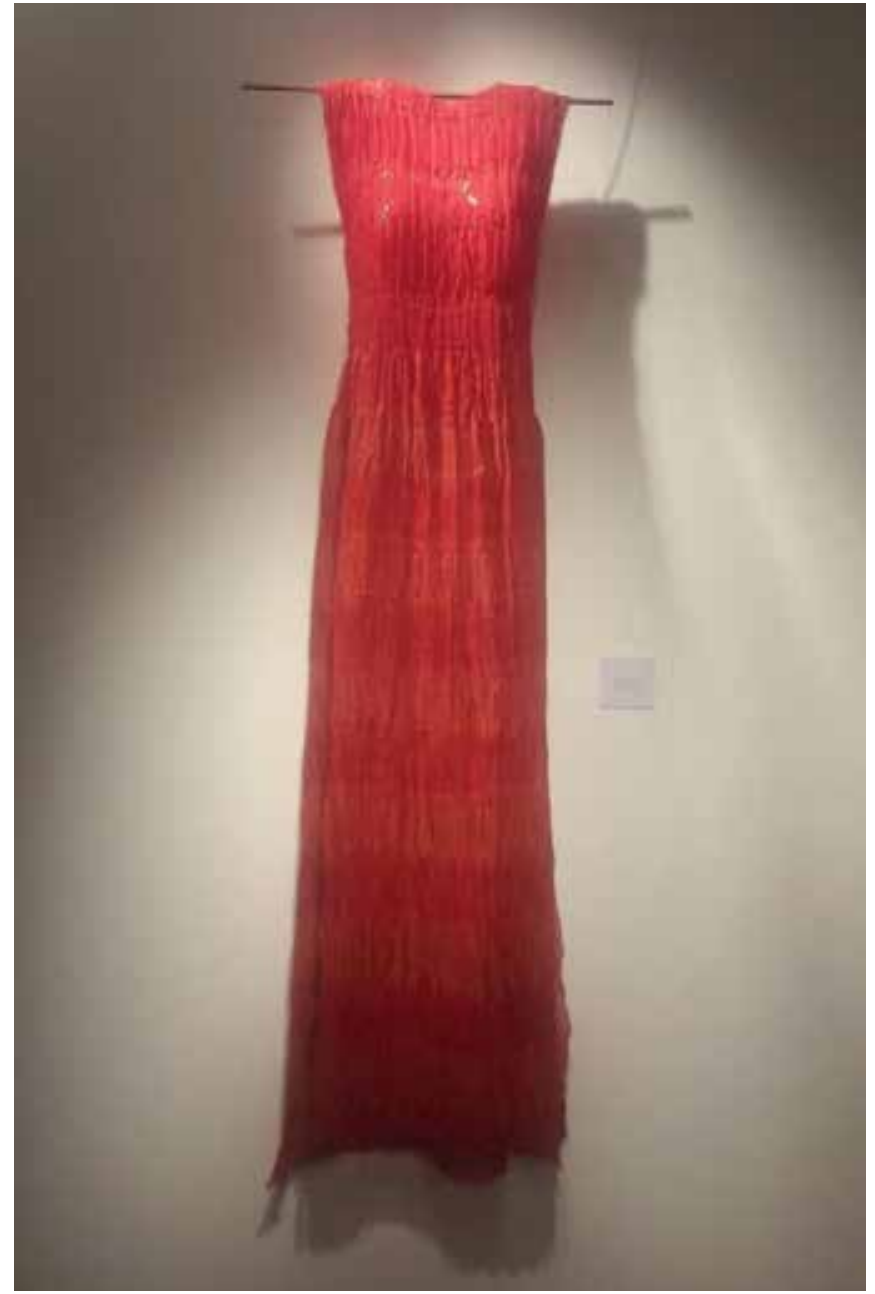

Resim 15. 'Kırmızı Güç’, Neslihan Yaşar, 2015

denk gelen kumaş dokusu çok bükümlü krep ipek kullanıldığı için kumaş enini daraltmış ve üst bedeni saran giysi formuna kavuşmuştur. Giysinin etek bölümünde ise kumaşın bir katında ipek iplik, diğer katında ise keten iplik yer almaktadır. Üst bedene denk gelen krep iplikler kumaşı daraltarak sıkıştırmış, bel hizasından itibaren kumaşa dalgalı bir görünüm vermiştir. Resim 16'da keten ve krep ipek ipliklerin yer değiştirdiği dikişsiz bel bölgesi yer almaktadır.

Kumaş bitim işlemi uygulanmadan boyanmıştır. Bu nedenle ipeğin üzerinde bulunan serisin maddesi tam olarak çözülmemiş ve kumaşın çok yumuşaması engellenmiştir. 'Antik' adlı çalışmanın kumaşına göre daha diri ve daha hacimli bir kumaş elde edilmiştir.

Boyama işlemi kumaş dokusunda farklı renk tonları yaratmıştır. Çünkü selüloz esaslı keten ipliklerle protein esaslı ipek ipliklerin boyayı çekme özellikleri farklıdır. Bu durum elbisenin kumaşında ipek ve keten ipliklerin ışığı

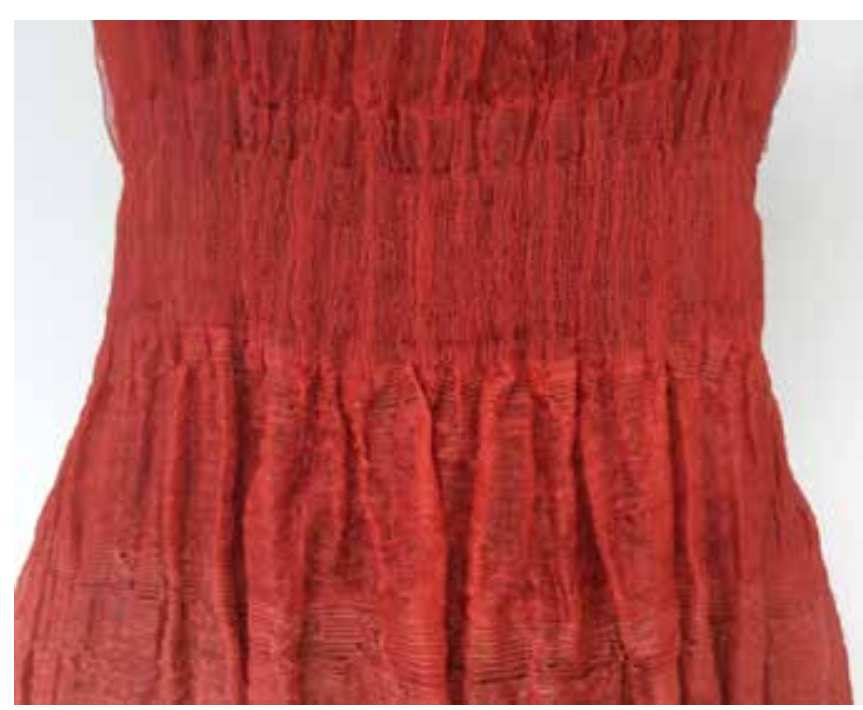

Resim 16. 'Kırmızı Güç’ adlı çalışmanın detayı

yansıtma özelliklerinden ve örgü-kumaş yapısı gibi faktörlerin de etkisiyle kırmızının birkaç tonu elde edilmiştir. Elbisenin etek kısmı üst bedene göre daha parlak ve ışıltılı bir görünüme sahip olmuştur. Bunda üst bedende kullanılan çok bükümlü krep ipek atkı ipliklerinin, bükümünden dolayı parlama özelliklerinin azalması da etkilidir.

'Hayalperest', 'Antik' ve 'Kırmızı Güç' adlı çalışmalar kumaş yapıları ve giysi modelleri açısından birbirlerine benzemektedirler. Fakat her birini diğerlerinden ayıran çok büyük farklar da vardır. Örneğin, 'Hayalperest' adlı çalışmanın kumaşı, yapma bir lif olan elastanlı bir iplikle dokunarak çift katlı kumaş yapısının da etkisiyle çok hacimli görsel değeri güçlü bir kumaş görünümüne sahiptir. Ayrıca kumaşa bitim işlemi uygulanmadığı için bu etkiler diğerlerine göre çok daha fazladır. Çünkü serisinli ipek kumaş, elastan ipliğin arasında spreyle sabitlenmiş gibi sert bir tutuma sahiptir. Kumaş bu sebeple dökümlü bir yapıda değildir. 'Antik' adlı çalışmanın kumaşına bitim işlemi uygulandığından içlerinde en fazla dökümlü olan dolayısıyla da en az dokulu yapıda olan giysidir. Bu da kumaşın ağırlaşmasına ve kabarık hacimli etkilerin, kumaşın sarkmasından dolayı azalmasına sebep olmaktadır. Kumaşı sıkıştırması ve çekme gücü bakımında elastan ipliğin krep ipek ipliğine göre daha fazla olduğu görülmektedir. Kırmızı güç adlı çalışma ise bitim işlemi uygulanmadığı için çok yumuşamamış fakat boyanma işleminden sonra Hayalperest adlı çalışmaya göre daha dökümlü bir yapıya bürünmüştür.

Tek parça kumaştan oluşan 'Şımarık' adlı etol, Resim 17 'de görülmektedir. Kumaş tek-çift katlı değişen yüzlü 


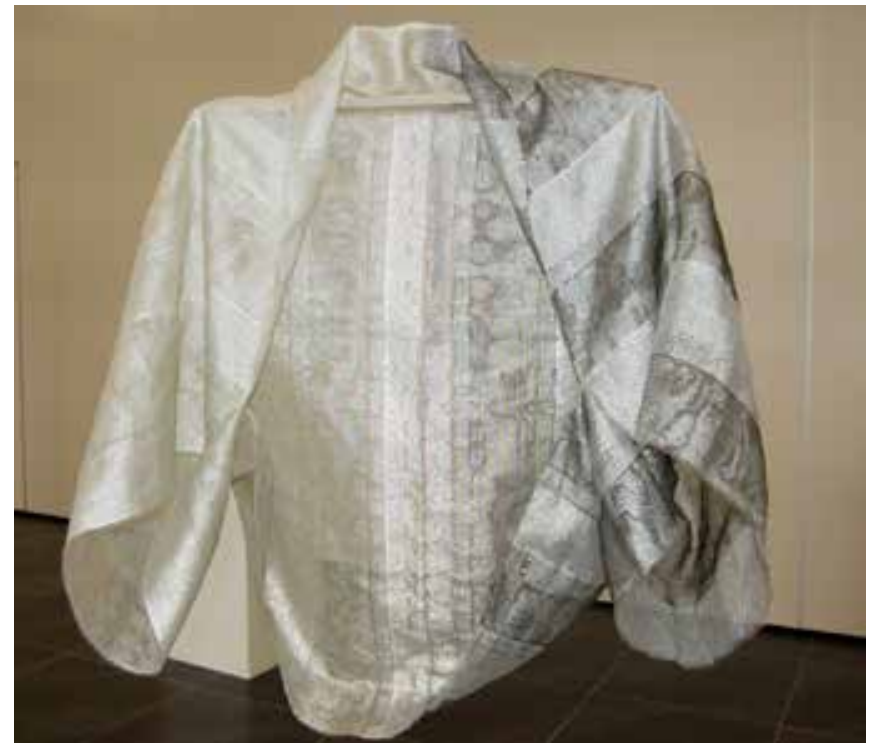

Resim 17. 'Şımarık', Neslihan Yaşar, 2015

dokuma yapısında üretilmiştir. Bezayağı örgüsüyle dokunmuştur. Örgü raporu, armür planı gibi dokuma kumaş yapısı bakımından 'Kırmızı Güç' adlı çalışmanın dokuma yapısıyla aynıdır. Atkı iplik farklılıkları ve atkı sıklık değerleri kumaşları farklı görünümlere taşımaktadır.

Resim 17 'de görüldüğü üzere, ipek ve retro-reflektif ipliklerin etkisiyle parlak, ışıltılı ve gösterişli yarı-şeffaf bir kumaştır. Reflektif iplikten dolayı üzerine gelen ışığı geri yansıtma özelliği nedeniyle, giyen kişinin konumuna göre kumaş, görsel olarak farklı parlama özelliklerine sahiptir. Kumaşın parlak bir etkiye sahip olmasının başka bir sebebi de kumaş dokusunun şeffaflık özelliğinin yüksek olması ve çözgüde kullanılan ipek ipliklerin parlamasıdır. Kumaş basit bir dikiş yöntemiyle etol formuna dönüştürülmüştür. Etolün yarısı krem-gri renkli iken diğer yarısı, atkı ipliğinin ipek iplikle siyah pamuk ipliğinin değişimi sonucu gri-siyah renklidir. Böylece etolün bir tarafında renk değişimi sonucu kumaşın kalın çizgili deseni ortaya çıkmış, asimetrik bir görünüme sahip olmuştur. Kumaş bitim işlemi uygulanmadan dikildiği için sert bir yapıdadır. Ancak parlama özelliği ile birlikte kumaş, yumuşakmış gibi bir etki kazanmaktır.

Resim 18'de yer alan 'Marjinal' adlı çalışma, ipek çözgü üzerinde aynı armür kullanılarak atkıdan krem ipek ve siyah pamuk ipliklerinin ardarda dokunması sonucunda renk değişikliği ile farklılaşan tek parça kumaştan üretilmiştir. Ancak, diğer giysi tasarımlarının aksine giysi formu basit de olsa kalıplar yardımıyla oluşturulmuştur. İki renkli

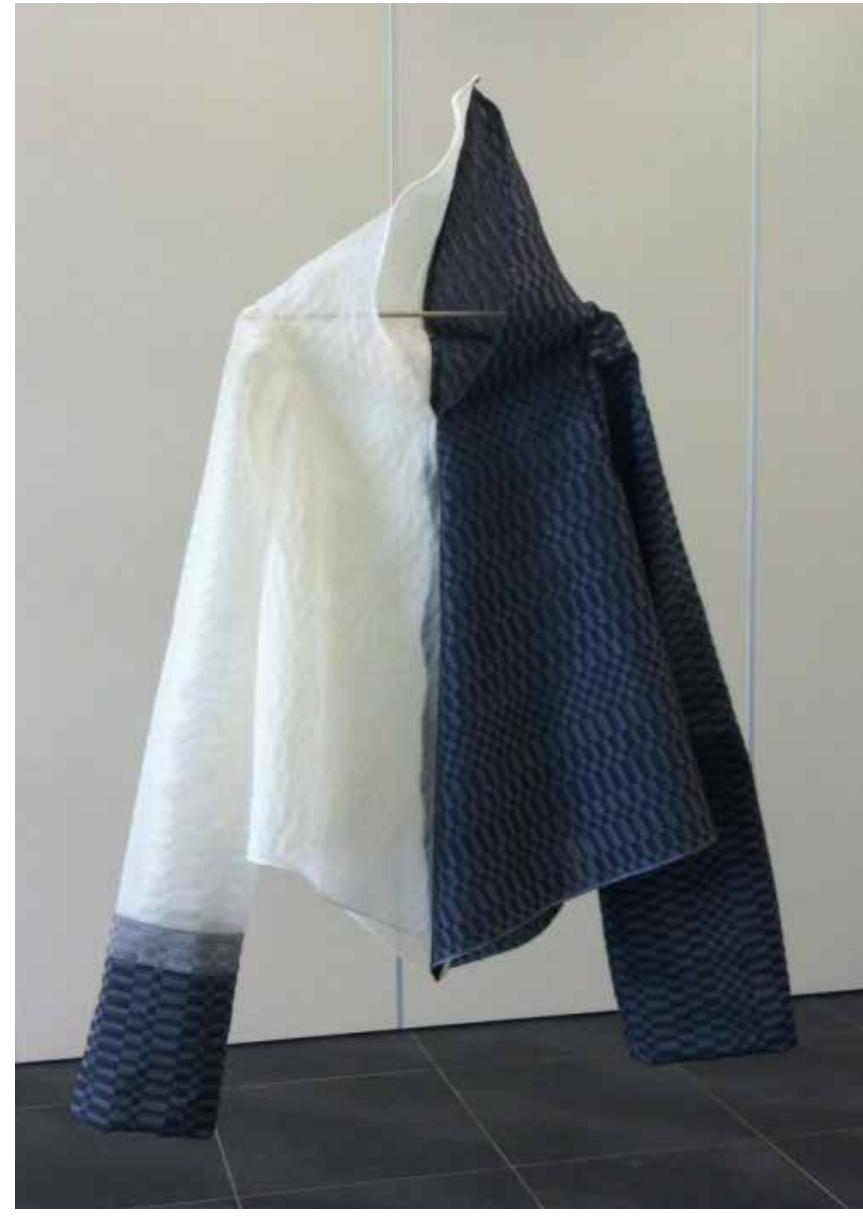

Resim 18. 'Marjinal', Neslihan Yaşar, 2015

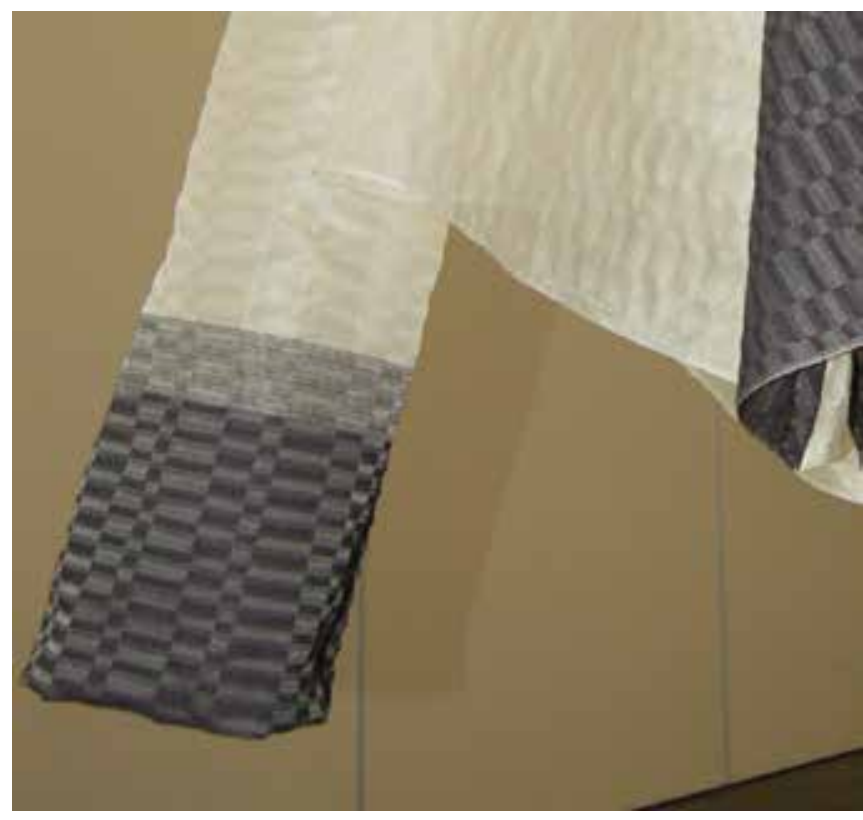

Resim 19. 'Marjinal' adlı çalışmanın detayı 
bir gömlek formundaki giysinin farklı ve özel olan kısmı sağ kolundaki renk değişimi bölgesidir. Resim 19'da yer alan detayda sadece tek kolda kullanılan ve atkı ipliklerinin yer değiştirdiği geçiş bölgesi dikkati o noktaya çekmektedir. Kumaşın renk değiştirdiği bölgede keskin bir değişim yerine krem ve siyah ipliklerin tekrarlı kullanımları sonucu gri renkli bir bölge meydana gelmiştir. Bu da kumaşta koyu renkli yarı-şeffaf bir doku yaratmıştır. Gömleğin sol tarafı ipek kumaşın şeffaf özelliklerinden dolayı ışığı geçirgen bir yapıdayken sağ tarafı daha kalın ve siyah pamuk ipliklerinden dolayı opak bir görünümdedir. Birbirine zıt şeffaf-opak kumaş dokuları ve renkler aynı giysi üzerinde kullanılmıştır.

\section{Sonuç}

Araştırma kapsamında incelenen kumaşlar dokumanın olanakları kullanılarak malzeme ve kumaş yapısı ekseninde tasarlanmış ve üretilmişlerdir. Elde edilmiş olan kumaş dokuları tasarım aşamasında planlanarak, deneme yanılma yöntemleri kullanılarak, uzun bir üretim sürecinden geçmiştir. Araştırma kapsamında hazırlanan giysilerin üretildiği tek parça kumaşlarda elde edilen doku farklılıkları ve görsel etkiler tek tek incelenmiştir.

Makalede yer alan beş giysi çalışmasında on bir farklı kumaş dokusu elde edilmiştir. Atkı ipliklerinin kumaşa kazandırdıkları farklı doku, tutum, renk ve desen özellikleri baz alınarak kumaşı en iyi ifade edecek ve kumaşın özelliğini ön plana çıkaracak basit giysi formlarında sunulmuştur. Bunun sebebi kumaşların sahip olduğu güçlü görsel etkileri ön plana çıkarmak ve kumaş tasarımının önemine dikkat çekmektir.

Elde edilen dokuma kumaşlarda iplik özelliklerinin giysi formlarına hem işlevsel hem de görsel açıdan birçok etkisinin olduğu görülmüştür. Bunlardan bazıları, krep ipek iplik ve elastan içeren ipliğe bağlı olarak giysinin bedeni sarması, beden ölçüsüne göre esneme özelliğinin olması, kumaşın hammadesine bağlı olarak sert veya yumuşak olması, dökümlü olması, kumaşın dökümlülük etkisine bağlı olarak giysinin kabarık etkilerinin azalması, giysilerin ipek ve reflektif ipliklere bağlı olarak parlak olması, aynı giysi üzerinde şeffaf ve opak, mat ve parlak dokuların birlikte kullanılmasıdır.

Bu makalede olduğu gibi doğal liflerle yeni teknolojik liflerin birlikte kullanılma biçimi veya kişiye ya da tasarıma özgü kumaşların üretilerek giysilerde kullanımı, dokuma ve giyim endüstrisi için yeni fikirler içermektedir. Teks- til tasarımında disiplinlerarası çalışmaların yansımaları artmaktadır. Bu kadar büyük bir endüstrinin içinde özel kumaşların önemi anlaşılmıştır. Benzer çalışmalar, benzer düşüncelerle ev tekstili kumaşlarında da yapılabilir.

\section{Kaynakça}

Arn-Grischott, Ursina (1997). Doppelgewebe in der Handweberei, Italy: Verlag Paul Haupt, Die Deutsche Bibliothek

Atalayer, Günay (2011). “ Tekstil Sanatları Eğitiminde Bauhaus’un İzleri Üzerine”. Bauhaus: Modernleşmenin Tasarımı, Türkiye'de Mimarlık, Sanat, Tasarım Eğitimi ve Bauhaus, Der: Ali Artun ve Esra Aliçavuşoğlu, İstanbul: İletişim Yayınları 1381

Başer, Güngör (1998). Dokuma Tekniği ve Sanatı, Cilt1, İzmir: TMMOB Tekstil Mühendisleri Odası Yayınları No.2

Clarke, Sarah E. Braddock \& O’Mahoni, Marrie (2005). Techno Textile 2, Revolutianary Fabrics For Fashion And Design , Chi ne: Thames and Hudson

Cohen, Allen C. ve Johnson, Ingrid (2012). J. J. Pizzuto's Fabric Science, USA : Fairchild Books

Colchester, Chloë (2007). Textiles Today, A Global Survey of Trends and Traditions, China: Thames\&Hudson Ltd

Cole , Drusilla (2008). Textiles Now, China: Laurence King Publising

English, Bonnie (2011). Japanese Fashion Designers, The Work And Influence of Issey Miyake, Yohji Yamamoto and Rei Kawakubo, United Kingdom: Berg-Bloomsbury Publishing

Gale, Colin ve Kaur, Jaspir (2002). The Textile Book, New York: Berg-0xfort International Publishers Ltd.

Holborn, Mark (1995). Issey Miyake, Germany: Benedikt Taschen Verlag GmbH,

Larsen, Jack Lenor ve Weeks, Jeanne (1975). Fabrics For Interiors, A Guide For Architects, Designers, and Consumers, USA: John Wiley \& Sons

Lee, Suzanne (2005). Fashioning The Future, Tomorrow's Wardrobe, London: Thames \& Hudson Ltd.

Önlü, Nesrin ve Yaşar, Neslihan (2011). “Visual Textures Combined with Metallic, Retro-Reflective and Stainless Steel Yarns in Semi-Transparent Fabrics" Research Journal of Textile and Apparel, ( 15/1): 22-33

Önlü, Nesrin (2008). “Değişen Yüzlü Dokuma Kumaşlarda Farklı Malzeme, Dokuma Tekniği, Örgü ve Renk Kullanımıyla Görsel Etkilerin Elde Edilmesi”, Tekstil ve Mühendis, (13/64): 9-18 
Quinn, Bradley (2013). Textile Visionaries, Innovation and Sustainability in Textile Design, China: Laurence King Publishing,

Quinn, Bradley (2009). Textile Designers, At The Cutting Edge, China: Laurence King Publishing,

Shenton, Jan (2014). Woven Textile Design, China: Laurence King Publishing,

Fukai , Akiko (2006). Fashion, A History from the 18th to the 20th Century, Volume II: 20th Century, China: The Kyoto Costume Institude, Taschen $\mathrm{GmbH}$,

Thorpe, Azalea Stuart ve Larsen, Jack Lenor (1978). Elements of Weaving, A Complete Introduction To The Art And Techniques, New York: Doubleday \& Company

Tunalı, İsmail (2004). Tasarım Felsefesine Giriş, İstanbul: YapıEndüstri Merkezi A.Ş.

Udale, Jenny (2014). Moda Tasarımında Tekstil ve Moda, Çev: Hayriye Güngör, İstanbul: Literatür Yayı

\section{Görsel Kaynaklar}

Resim 1: Jakarlı parlak kumaş örneklerinden yapılmış giysi örnekleri (Baugh,2011:101)

Resim 2: İpek, pamuk, keten, kağıt ve metalik ipliklerle dokunmuş bir kumaş örneği “Indigo Map Stripe” Ismini Samanidou, 40x175cm (Cole,2008:45)

Resim 3: İpek ve termoplastik ipliklerle dokunmuş ve kırışık etkiler taşıyan etek örneği Prada 2007 Sonbahar-Kış koleksiyonu (Udale,2014:68)

Resim 4: Vücudun nem dengesini sağlayan liflerden üretilmiş giysi (Quinn,2012:201,200)

Resim 5: Bir bölümüne shibori uygulanmış tek parça kumaştan tasarlanmış elbise. “Coat Dress”, Yohji Yamamato, 1995 İlkbahar-Yaz Koleksiyonu, （Fukai,2006:659)

Resim 6: "Shrunk Kibira", Keten ve rafya iplikler dokunmuş kumaştan üretilmiş ceket Issey Miyake 1993 İlkbahar-Yaz koleksiyonu (Holborn,1995:121)

Resim 7: "Partially Crushed \& Tied, Bağlama yöntemiyle kırıştırılmış ve bölgesel müdahale ile değiştirilmiş giysi, Issey Miyake, 1993/94 Sonbahar-Kış Kol. (Holborn,1995:122,123)

Resim 8: A-POC koleksiyonundan bir parça. Uzun veya kısa kollu olarak giyilecek tişört rulosu. "Yellow Baguette Roll”, Issey Miyake (Clarke ve 0’Mahoni,2005:123)

Resim 9: Kumaşın ipek atkı ipliği ile dokunan bölümü, detay, Neslihan Yaşar Fotoğraf: Sertaç Algüney

Resim 10: Kumaşın elastan atkı ipliği ile dokunan bölümü, detay, Neslihan Yaşar Fotoğraf: Sertaç Algüney
Resim 11: “Hayalperest”, Neslihan Yaşar, 2015 , Fotoğraf: Sertaç Algüney

Resim 12: “Hayalperest”, Neslihan Yaşar, detay, Fotoğraf: Sertaç Algüney

Resim 13: 'Antik' , Neslihan Yaşar, 2015, Fotoğraf: Sertaç Algüney

Resim 14: 'Antik', Neslihan Yaşar, detay, Fotoğraf: Sertaç Algüney

Resim 15: 'Kırmızı Güç', Neslihan Yaşar, 2015 Fotoğraf: Sertaç Algüney

Resim 16: 'Kırmızı Güç’, Neslihan Yaşar, detay Fotoğraf: Sertaç Algüney

Resim 17: 'Şımarık', Neslihan Yaşar, 2015 Fotoğraf: Sertaç Algüney

Resim 18: 'Marjinal', Neslihan Yaşar, 2015 Fotoğraf: Sertaç Algüney

Resim 19: 'Marjinal', Neslihan Yaşar, detay Fotoğraf: Sertaç Algüney 